\title{
A plan for evaluating a small library collection
}

\section{By Frances Davis}

\section{Enlisting support and involving the faculty are keys to success}

wensboro Community College is a sixyear-old institution with an FTE enrollment of 1,494, a head count enrollment of over 2,800 , and a library book collection of approximately 14,000 titles. Many hours were spent in the first six years reviewing and selecting titles to build an adequate collection, which began at zero. After those efforts, the library staff felt it was time for a comprehensive evaluation of what had been collected, realizing the inevitability of weak areas and the possibility of blank areas in the collection.

The Learning Resource Center (LRC) director first discussed the need with the Instructional Resources Committee at its January 1991 meeting. The committee consists of the director as chair, four faculty and one college staff member appointed by the president, and two students. The academic dean, the dean of business affairs, and the director of the learning skills center are ex officio members and attend occasionally. The group felt the need was justified and agreed to help. The academic dean expressed his willingness to lend his support, and we felt we had a good base of support to begin. Ideas were discussed and the committee made suggestions on how we should proceed to make the scheme successful.

\section{Devising a plan}

The director's background search found no workable design and very little advice on how to devise a plan of action for an effective evaluation. "Guidelines for the Evaluation of the Effectiveness of Library Collections" from the book published by ALA, Guidelines for Collec- tion Development (1987), was probably the most helpful in getting us started because it gave a quick survey of the essential elements of evaluation and the advantages and disadvantages of each.

A rough draft of a plan was prepared and presented to the committee in April 1991. It consisted of strategies for getting faculty involved, logistics for implementing the project, and a method for faculty to use in reporting the results. A worksheet was designed as a guide for faculty to use in carrying out their part of the evaluation. It stated the goal of the project and suggested ways both to prepare for the implementation and to report on findings and recommendations (see "Collection evaluation worksheet" at the end of this article).

The plan was refined and the committee determined to implement the plan the following academic school year. It was decided that the dean and/or committee members would present the proposal to the faculty at one of their regular meetings in the fall and a date would be set that would be most convenient for faculty. Follow-up details on the actual implementation of the plan would be presented in division meetings by the LRC director.

\section{Selling the plan}

The proposition was announced as planned. With input from faculty, the date was set for a three-week period beginning February 24 through March 13, 1992, after midterms but before finals. Each division was assigned one of the three weeks, and the director asked each division chair to place her name on the agenda for their next division meeting so she could present the details of the plan to the faculty and answer any questions.

At each division meeting, the LRC director briefly reviewed the project and discussed its 
purpose. Members of each discipline were asked to choose a date and time during their week to meet with each other and the director for the execution of the plan. Instruction/ worksheets were handed out and discussed, and faculty were given their assigned area of the collection; for example, English faculty who primarily taught American literature were given the Library of Congress area "PS." A great deal of time was spent before these meetings by the director "fitting" the proper faculty with the proper subject area and also finding additional areas where cross-disciplinary or additional books on the topic might fit. For example, psychology faculty assigned "BF" were told books on mental health could be found in "RC 321571." Some faculty did not "Fit" with their assigned area as well as others, but remaining flexible to changes or adjustments solved most problems. Faculty were encouraged to complete numbers 1 through 4 on the worksheet before their first meeting so they would be adequately prepared to participate.

Reminders were sent to each faculty member a few days before each scheduled meeting. The director had cleared her three weeks in order to be free to facilitate the entire program. Most of the faculty came to the LRC at their convenience prior to the scheduled meeting as requested on the worksheet. When they came to the first meeting, the director was there to facilitate the process, answer any questions, help when asked, but otherwise stay out of the way. Second meetings were scheduled when needed. A great deal of leeway was given to groups in completing their part of the project.

Because of the enthusiasm of the Instruc- tional Resources Committee and the support of the academic dean, there was almost total support for the project. A few meetings had to be rescheduled and several reports were completed late, but polite reminders resulted in all but 5 out of 51 teaching faculty giving input into the evaluation by the end of the semester.

Although our collection is still very small, I think this plan might also be used successfully with a larger collection. I know the faculty are more aware now of what is available in the LRC, and in the future they will be more spontaneous in making recommendations for developing the collection. Overall, it was a very successful project. The unfinished part is going through the faculty's completed worksheets and materials and handling the requests and suggestions for the improvement of the collection. That will be a joy.

\section{Collection evaluation worksheet}

GOAL: To determine areas in our library collection that need to be targeted for future collection development. The goal is not a balanced collection necessarily, although some balance is desired. The goal is a collection that supports our areas of instruction. (See Collection Development Policy)

1. Before looking at assigned area of evaluation, jot down topics that you feel should be covered. Place asterisks by those you feel are more important and/or more popular and would require broader coverage. Think about the topics your students use for:
(a) research or topical papers
(b) reports or speeches
(c) supplemental help for difficult subjects
(d) supplemental readings

2. Make a list of any "must" titles in your area that you feel should be in the collection. (Keep in mind the question, "Will students use the title?").

3. Spend some time browsing in the assigned area to get a feel for it, noting any topics that you may have missed.

4. Using your list of topics, list any areas with no titles or areas that need broader coverage. Please be as specific as possible.

5. Photocopy any of your textbook bibliographies that have titles you would like to see in our library. Highlight those titles. (Be aware that many of them may be out of print, but we can try!) 


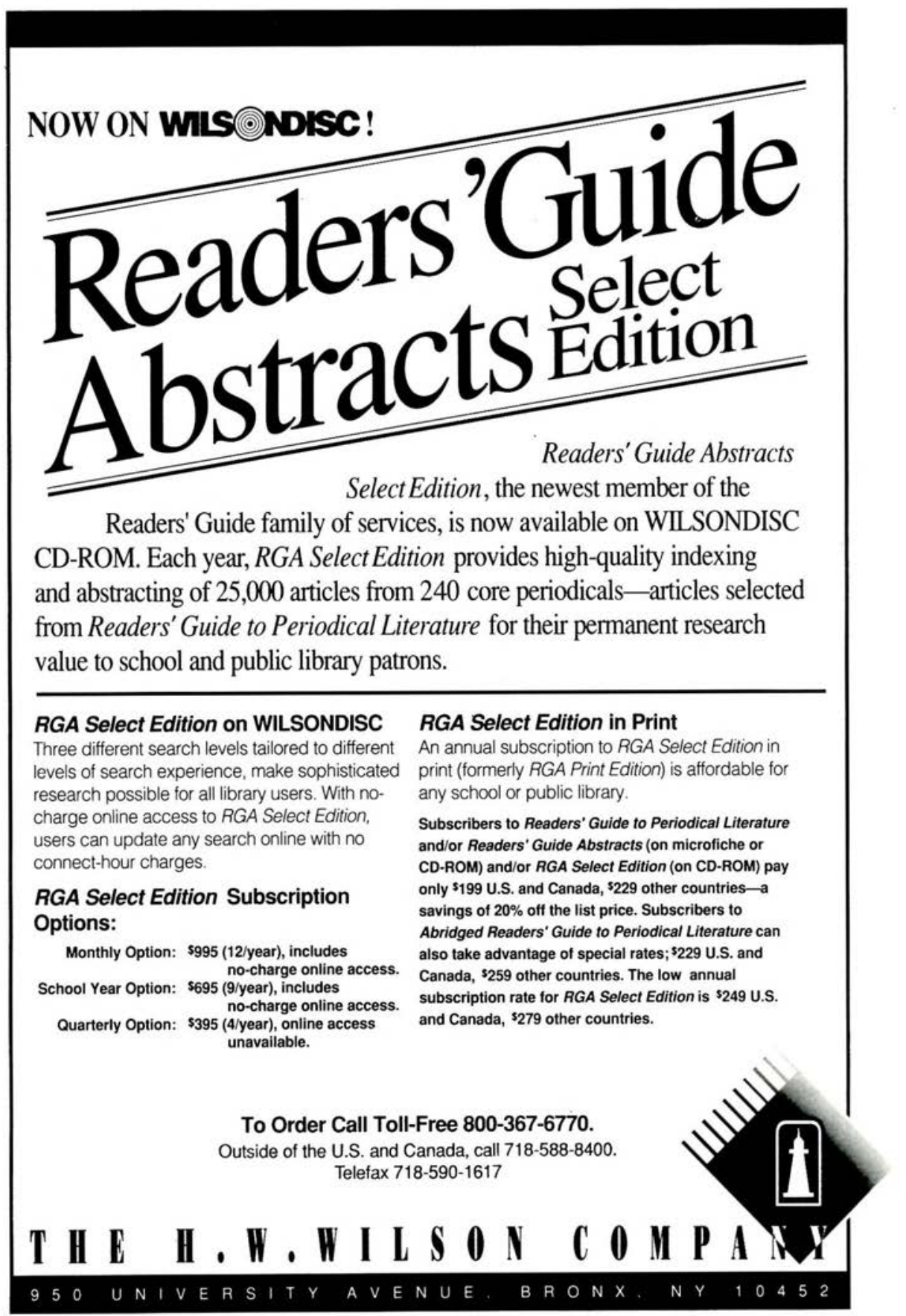

